\title{
Pengembangan Lembar Kerja Peserta Didik Berbasis Pemecahan Masalah Kontekstual Materi Masalah Sosial Kelas IV SD
}

\section{Made Rai Aditya Wiranata ${ }^{1 *}$, I Wayan Sujana}

\author{
${ }^{1}$ Prodi Pendidikan Guru Sekolah Dasar, Universitas Pendidikan Ganesha, \\ SIngaraja, Indonesia \\ *e-mail: imaderaiadityawiranata04@undiksha.ac.id
}

\begin{abstract}
Abstrak
Penelitian pengembangan ini dilaksanakan berdasarkan kesulitan guru untuk mengembangkan media pembelajaran yang membuat peserta didik sulit belajar secara aktif dan mandiri dalam pembelajaran. Penelitian ini bertujuan untuk menguji kelayakan LKPD berbasis pemecahan masalah kontekstual pada muatan materi masalah sosial kelas IV SD. Penelitian ini merupakan penelitian pengembangan menggunakan model ADDIE. Data yang dikumpulkan dalam penelitian ini adalah data kuantitatif dan data kualitatif. Metode yang digunakan untuk mengumpulkan data yaitu: metode observasi, wawancara, dan angket. Subjek yang terlibat dalam penelitian ini adalah 2 orang pakar, 3 orang pada tahap uji perorangan dan 12 orang pada tahap uji kelompok kecil. Teknik analisis data yang digunakan adalah teknik analisis data deskriptif kuantitatif dan kualitatif. Hasil penelitian menunjukkan bahwa kelayakan LKPD dari aspek isi mata pelajaran memperoleh persentase $93,33 \%$ dengan kualifikasi sangat baik, pada aspek desain pembelajaran memperoleh persentase $95,00 \%$ dengan kualifikasi sangat baik, pada aspek media pembelajaran memperoleh persentase $89,58 \%$ dengan kualifikasi baik. Pada uji coba perorangan diperoleh sebesar $92,50 \%$ dengan kualifikasi sangat baik dan uji coba kelompok kecil sebesar $90,83 \%$ dengan kualifikasi sangat baik. Dengan demikian, LKPD memiliki kelayakan dari aspek isi, desain, media, serta uji coba pengguna.
\end{abstract}

Kata kunci: lembar kerja, pemecahan masalah, kontekstual

\begin{abstract}
This development research was carried out based on the difficulty of the teacher to develop learning media that made it difficult for students to learn actively and independently in learning. This study aims to test the feasibility of LKPD based on contextual problem solving on the content of social problems in class IV elementary school. This research is development research using the ADDIE model. The data collected in this study are quantitative data and qualitative data. The methods used to collect data are observation, interview, and questionnaire methods. The subjects involved in this study were 2 experts, 3 people at the individual test stage, and 12 people at the small group test stage. The data analysis technique used is descriptive quantitative and qualitative data analysis techniques. The results showed that the feasibility of LKPD from the content aspect of the subjects obtained a percentage of 93.33\% with very good qualifications, in the learning design aspect obtained a percentage of $95.00 \%$ with very good qualifications, on the aspect of learning media obtained a percentage of $89.58 \%$ with good qualifications. In individual trials, it was obtained $92.50 \%$ with very good qualifications, and in small group trials of $90.83 \%$ with very good qualifications. Thus, LKPD has the feasibility of the aspects of content, design, media, and user trials.
\end{abstract}

Keywords: development, student worksheets, problem solving

\section{Pendahuluan}

Pembelajaran adalah sebuah proses ilmiah mulai dari mengatur, mengorganisasi lingkungan yang ada di sekitar peserta didik sehingga dapat menumbuhkan dan mendorong peserta didik untuk melakukan suatu kegiatan belajar (Pane \& Darwis Dasopang, 2017). Belajar merupakan dari bagian dari pembelajaran yaitu proses perubahan tingkah laku seseorang yang berlangsung secara aktif dan integratif serta 
terjadi secara terus menerus sesuai dengan perkembangan psikis dari seseorang (Oktiani, 2017; Rahmayanti, 2016). Pembelajaran yang baik adalah pembelajaran yang melibatkan peserta didik secara aktif di dalamnya dan membuat peserta didik senang, termotivasi serta merasa tertarik untuk belajar mengenai sesuatu yang baru, sehingga peserta didik mampu membangun pengetahuannya sendiri dan membuat pembelajaran menjadi bermakna (Faridah et al., 2019; Widyanto, 2020). Untuk membuat kegiatan pembelajaran lebih bermakna maka diperlukan berbagai sumber belajar seperti media pembelajaran, bahan ajar, lembar kerja siswa, alat peraga, dan sumber belajar lainnya.

Berdasarkan hasil observasi yang dilakukan pada SD No. 1 Sempidi, Kecamatan Mengwi, Kabupaten Badung saat Pengenalan Lapangan Persekolahan berbasis (Daring PLPbD), ditemukan bahwa guru mempunyai kesulitan untuk mengembangkan media pembelajaran elektronik. Media yang ada lebih banyak cetak dan non elektronik. Terbatasnya media elektronik atau digital membuat peserta didik sulit memahami materi, cepat bosan dan tidak tertantang untuk belajar. Selain itu, dalam pembelajaran materi masalah sosial, guru juga mengalami kesulitan untuk mengajarkan materi tersebut karena cakupan materi masalah sosial sangat luas. Guru juga mempunyai permasalahan untuk mengembangkan media yang cocok digunakan pada materi masalah sosial tersebut mengingat cakupan materi tersebut cukup luas sehingga diperlukan media pembelajaran yang dapat mengefisienkan waktu dalam menjelaskan muatan materi tersebut. Kesulitan tidak hanya pada terbatasnya media tetapi juga karena terbatasnya sumber belajar lain seperti lembar kerja inovatif yang mendukung pembelajaran secara online dalam jaringan (daring). Lembar kerja yang selama ini digunakan hanya membuat soal-soal seperti bank soal, tipe soal menoton, dan sangat minim media dalam lembar kerja tersebut. Lembar kerja yang menoton, tampilannya kurang menarik, kurang gambar, petunjuk tidak jelas, pertanyaan terlalu banyak dapat membuat siswa jenuh dan menyulitkan mereka belajar (Hala et al., 2016; Suryani et al., 2019). Tentunya hal tersebut berdampak pada tidak optimalnya proses belajar siswa dan dapat menurunkan hasil belajar siswa.

Lembar kerja siswa atau lembar kerja peserta didik (LKPD) sangatlah membantu peserta didik memahami materi. LKPD merupakan salah satu alat untuk membantu dan memudahkan kegiatan pembelajaran sehingga terbentuk interaksi yang efektif antara pendidik dan peserta didik. Interaksi ini diharapkan dapat meningkatkan aktivitas peserta didik dalam meningkatkan hasil belajarnya (Jowita, 2017). Penyusunan LKPD dapat dirancang sesuaikan dengan kondisi kegiatan yang akan dilakukan. Melalui pengerjaan LKPD tersebut, guru dapat mengamati peserta didik yang telah memahami materi yang telah diberikan dan yang belum memahami materi yang diberikan (Widodo, 2017). Dalam proses pembelajaran menggunakan LKPD, peserta didik mendapatkan pengetahuannya sendiri dengan melakukan kegiatan sesuai dengan petunjuk LKPD, bukan dari penjelasan guru. Hal tersebut sejalan dengan teori belajar konstruktivisme yang cenderung memberikan ruang yang seluas luasnya kepada peserta didik untuk memahami sesuatu yang telah mereka pelajari dengan cara menerapkan konsep-konsep yang diketahuinya sehingga dapat diterapkan ke dalam kehidupan sehari-hari (Suparlan, 2019). Mengingat pentingnya peran LKPD maka dikembangkan LKPD inovatif. Inovasi yang ditawarkan dalam LKPD yang dikembangkan adalah berbasis pada pemecahan masalah-masalah kontekstual.

Kemampuan pemecahan masalah merupakan kemampuan penting yang harus dimiliki peserta didik (Cahyani \& Setyawati, 2016). Pemecahan masalah adalah usaha seseorang maupun sekelompok orang untuk menyelesaikan permasalahan dengan menggunakan pengetahuan, keterampilan serta pemahaman yang dimiliki oleh dirinya sendiri (Rizki, 2018; Salim Nahdi \& Cahyaningsih, 2018). Masalah-masalah kontekstual disajikan dalam LKPD dan didukung dengan penyajian gambar-gambar. Pemberian masalah dalam LKPD sangat layak digunakan dalam pembelajaran terutama di SD (D. Rahayu \& Budiyono, 2018). Pendekatan pemecahan masalah kontekstual yaitu berkaitan dengan pemberian masalah sesuai konteks kehidupan sehari-hari sehingga membuat peserta didik merasa tertantang dan aktif memecahkan masalah pada lingkungan sekitar 
mereka (Rando, 2017; Aprilia dkk., 2020). Masalah kontekstual adalah permasalahan yang sesuai dengan situasi yang dialami peserta didik dan sesuai dengan kehidupan nyata serta dekat dengan peserta didik (Rizki, 2018; Faridah dkk., 2019). Melalui pendekatan kontekstual guru dapat memancing peserta didik dengan pertanyaan agar peserta didik mengalami tindakan dan menemukan jawabannya sendiri. Sejalan dengan hal tersebut, maka LKPD berbasis pembelajaran kontekstual sangat valid diterapkan di sekolah dasar (Rahmawati, 2017).

Pengembangan LKPD berbasis pemecahan masalah kontekstual sangatlah penting dilakukan dan diterapkan di sekolah dasar karena unsur inovatif yang ditonjolkan pada LKPD adalah muatan masalah kontekstual dan didukung oleh media gambar yang menarik sehingga siswa menjadi lebih termotivasi memecahkan masalah. Pengembangan ini didukung oleh beberapa hasil penelitian yang menunjukkan bahwa LKPD mampu mempermudah siswa mengkonstruksi pengetahuan, memiliki retensi, dan meningkatkan hasil belajar siswa (Hala et al., 2016; Suryani et al., 2019). Untuk itu tujuan dalam penelitian ini adalah mengembangkan LKPD berbasis pemecahan masalah kontekstual yang valid dari aspek isi, media, dan desain pembelajaran serta layak digunakan dalam pembelajaran khususnya pada muatan materi masalah sosial di kelas IV Sekolah Dasar.

\section{Metode}

Jenis penelitian ini adalah penelitian pengembangan. Menurut Hanafi (2017), penelitian merupakan upaya untuk mengembangkan ilmu pengetahuan dan mendapat temuan-temuan yang baru. Model pengembangan yang digunakan adalah model ADDIE (Analyze, Design, Development, Implementation, Evaluation). Menurut Tegeh dkk. (2014) Model ADDIE adalah model yang dapat memberikan kesempatan untuk melakukan evaluasi terhadap aktivitas pengembangan produk pada setiap tahap. Penelitian ini dilakukan di SD No. 1 Sempidi Kecamatan Mengwi, Kabupaten Badung. Subjek uji coba pada penelitian ini adalah 1 orang ahli isi, 1 orang ahli media, dan 1 orang ahli desain pembelajaran. Setelah LKPD dinilai oleh para pakar selanjutnya diujicobakan ke siswa dalam skala terbatas. Pada tahap uji coba perorangan dilibatkan 3 orang siswa kelas IV dengan karakteristik yang berbeda-beda dan pada tahap uji coba kelompok kecil dilibatkan 12 orang siswa dengan karaktersitk yang berbeda-beda pula. Metode pengumpulan data dalam penelitian ini menggunakan metode observasi, wawancara dan angket. Observasi digunakan saat analisis lingkungan sekolah terutama ketersediaan sumber belajar. Wawancara digunakan untuk mengetahui kebutuhan, permasalahan guru dalam melaksanakan pembelajaran sehingga akan diketahui analisis isi atau konten yang digunakan dalam LKPD. Angket digunakan saat menilai validitas LKPD dari aspek isi, media, dan desain pembelajaran. Angket juga digunakan untuk mengukur kelayakan LKPD pada saat uji coba perorangan dan kelompok kecil.

Metode analisis data dalam penelitian ini adalah metode deskriptif kualitatif dan metode deskriptif kuantitatif. Menurut Agung (2014) metode analisis deskriptif kualitatif merupakan cara analisis atau pengolahan data dengan menyusun data secara terstruktur dalam bentuk kata-kata atau kalimat dan kategori mengenai objek sehingga akhirnya diperoleh kesimpulan umum. Teknik analisis data kualitatif ini dilakukan dengan mengelompokkan informasi-informasi dari data kualitatif yang berupa masukan, tanggapan, kritik, saran perbaikan yang terdapat pada angket dan hasil wawancara. Hasil dari analisis data ini selanjutnya dipergunakan sebagai acuan perbaikan atau revisi produk yang dikembangkan. Menurut Agung (2014), metode analisis deskriptif kuantitatif merupakan suatu cara pengolahan data yang dilakukan dengan menyusun secara sistematis dalam bentuk angka-angka dan atau persentase, mengenai objek yang diteliti, sehingga mendapat suatu kesimpulan umum. Analisis deskriptif kuantitatif digunakan dalam mengolah data kualitatif dari angket yang menggunakan skala Likert.

Persentase dari angket diperoleh dengan membandingkan jumlah keseluruhan jawaban responden dengan skor maksimal dan dikali $100 \%$. Kriteria pengambilan keputusan yang digunakan dalam penelitian pengembangan ini menggunakan konversi tingkat pencapaian dengan skala lima yang dapat dilihat pada tabel berikut. 
Tabel 2. Kriteria Kelayakan LKPD

\begin{tabular}{ccccc}
\hline No & Persentase Penguasaan & $\begin{array}{c}\text { Nilai } \\
\text { Angka }\end{array}$ & Nilai huruf & Predikat \\
\hline 1 & $90-100$ & 4 & A & Sangat Baik \\
2 & $80-89$ & 3 & B & Baik \\
3 & $65-79$ & 2 & C & Cukup \\
4 & $55-64$ & 1 & D & Kurang \\
5 & $0-54$ & 0 & E & Sangat Kurang \\
\hline & & & & \\
(Sumber: Agung, 2010)
\end{tabular}

\section{Hasil dan Pembahasan}

LKPD berbasis pemecahan masalah kotekstual dikembangkan menggunakan model ADDIE yang terdiri dari lima tahapan yaitu tahap analisis, tahap perancangan, tahap pengembangan, tahap implementasi, dan tahap evaluasi. Implementasi LKPD di lapangan tidak dilakukan mengingat masih masa pandemi Covid-19 yang membuat kegiatan pembelajaran tatap muka tidak dapat dilaksanakan. Tahapan pengembangan LKPD dapat dijelaskan sebagai berikut.

Tahap pertama adalah tahap analisis, pada tahap analisis kegiatan yang dilakukan adalah analisis karakteristik peserta didik, analisis isi atau konten, analisis lingkungan dan fasilitas siswa. Analisis karakteristik siswa dilakukan untuk mengetahui karakteristik siswa di SD No. 1 Sempidi. Metode yang digunakan untuk mengetahui karakteristik siswa adalah penyebaran angket. Berdasarkan angket yang disebarkan kepada siswa, disimpulkan bahwa masih banyak peserta didik yang bosan dan susah memahami materi masalah sosial. Selain itu penjelasan guru mengenai materi masalah sosial juga masih sulit untuk dipahami. Adapun buku penunjang yang dipergunakan peserta didik masih sulit untuk dipahami dan kurang memiliki warna dan gambar yang menarik sehingga cenderung membuat siswa bosan untuk belajar. Metode yang dipergunakan untuk menganalisis isi atau konten adalah metode wawancara tidak terstruktur dengan guru kelas. Berdasarkan wawancara yang dilakukan guru mengaku kesulitan mengembangkan media pembelajaran yang dapat menunjang guru dalam menyampaikan muatan materi. Selain itu, LKPD yang sering digunakan guru disekolah biasanya tidak dibuat sendiri dan peserta didik cenderung malas mengerjakannya karena dinilai menoton, terlalu banyak soal, dan tampilannya kurang menarik. Pada tahap analisis lingkungan dan fasilitas sekolah, metode yang digunakan adalah metode observasi dan hasilnya adalah masih kuranya ketersediaan sumber belajar.

Tahap kedua yaitu tahap perancangan, Tahap ini dikenal juga dengan istilah membuat rancangan (blue print). Kegiatan yang dilakukan pada tahap perancangan adalah (1) membuat rancang desain, (2) menentukan software dan hardware yang dipergunakan, (3) merancang desain cover LKPD, (4) merancang desain headers dan footers untuk LKPD, (5) menyusun Rencana Pelaksanaan Pembelajaran (RPP) dan (6) menentukan instrument penilaian produk.

Tahap ketiga yaitu tahap pengembangan, tahap pengembangan memiliki inti kegiatan merealisasikan blue print yang dirancang. Dalam tahap ini kegiatan yang dilakukan adalah (1) Pembuatan LKPD sesuai dengan tahap perancangan. Kegiatan pembuatan LKPD tersebut meliputi pengembangan desain pada isi LKPD, pencantuman langkah kerja dalam pengerjaan LKPD, pencatuman materi telah disusun pada tahap perancangan, menempatkan gambar yang sesuai pada materi yang dibahas dan penyajian soal-soal yang berisikan pemecahan masalah, (2) Membuat instrumen penilaian produk yang akan dinilai kelayakannya oleh ahli isi, ahli desain pembelajaran dan ahli media pembelajaran maupun uji coba ke peserta didik, (3) Melakukan uji kelayakan atau validasi produk yang telah dibuat. Kelayakan dari produk yang telah dibuat diuji oleh validator yaitu ahli materi, ahli desain pembelajaran dan ahli media pembelajaran, (4) Melakukan uji coba produk kepada uji coba perorangan dan uji coba 
kelompok kecil untuk mengetahui kelayakan produk yang digunakan dalam proses pelaksanaan pembelajaran. Adapun hasil pengembangan produk LKPD berbasis pemecahan masalah adalah sebagai berikut.

\section{Gambar 1. Hasil Pengembangan Produk LKPD Berbasis Pemecahan Masalah Kontekstual}
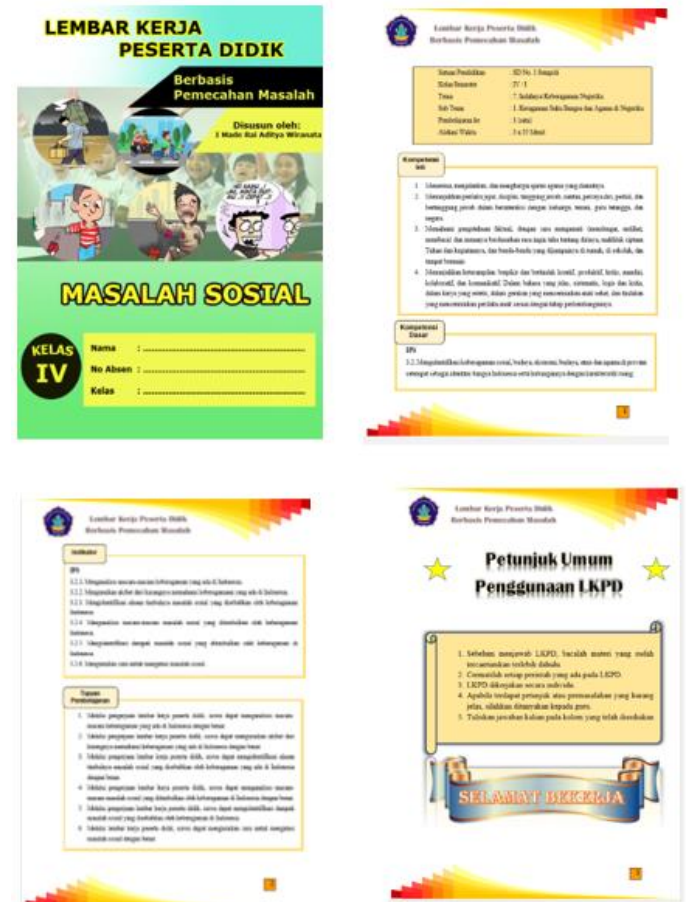
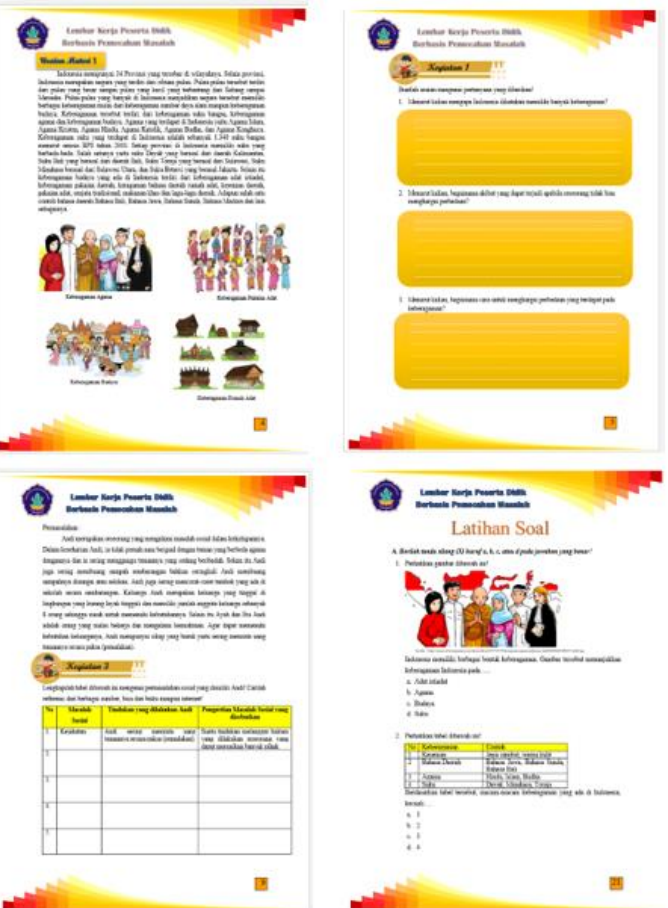

Terakhir adalah tahap evaluasi, kegiatan evaluasi ini dilakukan pada setiap tahapan dalam pengembangan. Hal tersebut dilakukan agar dapat meminimalisir kesalahan yang mungkin terjadi pada produk yang dibuat. Evaluasi yang dilakukan berupa evaluasi formatif yang digunakan untuk mengukur atau menilai produk yang mencangkup validasi ahli, uji coba perorangan dan uji coba kelompok kecil. Hasil yang diperoleh dari subjek uji coba digunakan sebagai acuan untuk memperbaiki atau penyempurnaan produk yang dikembangkan.

Hasil review oleh para ahli menunjukkan penilaian yang hampir sama terutama pada aspek isi dan desain pembelajaran. Pada tahap uji kelayakan menghasilkan skor yang berdekan sebagaimana terjadi pada Tabel 3.

Tabel 3. Persentase Kelayakan Produk berdasarkan Subjek Uji Coba

\begin{tabular}{cccl}
\hline No & \multicolumn{1}{c}{ Subjek Uji Coba } & Hasil Validitas (\%) & \multicolumn{1}{c}{ Keterangan } \\
\hline 1. & Uji Isi Mata Pelajaran & $93,33 \%$ & Sangat Baik \\
2. & Uji Desain Pembelajaran & $95,00 \%$ & Sangat Baik \\
3. Uji Media Pembelajaran & $89,58 \%$ & Baik \\
4. & Uji Perorangan & $92,50 \%$ & Sangat Baik \\
5. & Uji Kelompok Kecil & $90,83 \%$ & Sangat Baik \\
\hline
\end{tabular}

Berdasarkan hasil review dan uji coba produk yang telah dilakukan menujukkan bahwa validitas aspek isi memperoleh persentase sebesar 93,33\% berada pada kategori sangat baik, validitas aspek desain pembelajaran memperoleh persentase sebesar $95 \%$ berada pada kategori sangat baik, dan validitas aspek media pembelajaran sebesar $89,58 \%$ berada pada kategori baik. Hasil review para ahli digunakan sebagai acuan merevisi LKPD sehingga dapat diterapkan pada tahap berikutnya yaitu uji perorangan dan kelompok kecil. Pada tahap uji perorangan dan kelompok kecil diperoleh 
persentase sebesar $92,50 \%$ dan $90,83 \%$ dengan kategori sangat baik. Hal ini menandakan bahwa LKPD memiliki kelayakan yang sangat baik dan bisa diterapkan dalam pembelajaran yang sesungguhnya. Namun, dalam proses uji coba produk terdapat komentar dan saran dari ahli yang bersifat revisi yang dapat dijadikan pertimbangan untuk mepenyempurnaan produk yang dikembangkan. Adapun komentar atau saran yang diberikan oleh para ahli dan subjek uji coba disajikan pada Tabel 4.

Tabel 4. Komentar dan Revisi Produk LKPD

\begin{tabular}{|c|c|c|c|}
\hline No & Subjek Uji Coba & Komentar & Revisi \\
\hline \multirow[t]{2}{*}{1.} & $\begin{array}{l}\text { Ahli Isi } \\
\text { Pembelajaran }\end{array}$ & $\begin{array}{l}\text { Tambahkan materi sesuai } \\
\text { dengan perkembangan di } \\
\text { masyarakat. }\end{array}$ & $\begin{array}{l}\text { Menambahkan materi } \\
\text { mengenai keadaan masalah } \\
\text { sosial yang ada di } \\
\text { masyarakat. }\end{array}$ \\
\hline & & $\begin{array}{l}\text { Sesuaikan tujuan dengan } \\
\text { metode yang digunakan. }\end{array}$ & $\begin{array}{l}\text { Menyesuiakan tujuan } \\
\text { dengan metode yang } \\
\text { digunakan. }\end{array}$ \\
\hline 2. & $\begin{array}{l}\text { Ahli Media } \\
\text { Pembelajaran }\end{array}$ & $\begin{array}{l}\text { Warna Cover / Judul Cover } \\
\text { jangan menggunakan warna } \\
\text { merah } \\
\text { Tambahkan Identitas } \\
\text { Penulis } \\
\text { Pengaturan Huruf dan Jarak }\end{array}$ & $\begin{array}{l}\text { Merubah warna Cover / } \\
\text { Judul Cover menggunakan } \\
\text { warna kuning. } \\
\text { Menambahkan identitas } \\
\text { penulis pada cover belakang } \\
\text { LKPD. } \\
\text { Merubah tulisan pada LKPD } \\
\text { dengan menggunakan } \\
\text { Comic Sans MS dan } \\
\text { menambahkan shapes pada } \\
\text { sub judul LKPD. }\end{array}$ \\
\hline
\end{tabular}

Berdasarkan hasil penelitian yang telah dilakukan, pengembangan LKPD memperoleh kualifikasi sangat baik dari aspek isi mata pelajaran. Isi LKPD telah dikembangkan dengan mengacu dan memenuhi aspek (1) kurikulum, (2) susunan isi atau materi yang lengkap dan sistematis, (3), kesesuaian visualisasi materi, (4) penggunaan bahasa yang mudah dimengeti dan (5) penggunaan evaluasi berbasis pemecahan masalah kontekstual. Materi yang diulas dalam LKPD telah sesuai dengan kurikulum dan tujuan pembelajaran yang telah ditetapkan. Apa yang ada dalam LKPD tidak akan menyimpang dengan apa yang telah dibelajar oleh guru. Materi dalam LKPD telah disusun secara baik dan sistematis serta didukung oleh visualiasi gambar yang sesuai. Penyusunan secara sistematis sangat membantu peserta didik untuk mencapai standar kompetensi. Maka dari itu, dalam pengembangan LKPD pengemasan materi pelajaran telah dilakukan dengan baik dan dapat membantu peserta didik dalam kegiatan pembelajaran (Kristyowati, 2018). Pada aspek bahasa telah digunakan bahasa dengan kosakata yang sederhana dan tatanan kalimat yang lebih akrab dengan siswa. Siswa merasakan apa yang ia baca pada LKPD seperti sedang berkomunikasi dengan LKPD. Penerapan prinsip ini memberikan efek lebih baik kepada siswa ketika siswa akan menerapkan pengetahuannya (Rey \& Steib, 2013).

Hasil validiasi LKPD berbasis pemecahan dari aspek desain pembelajaran berada pada kualifikasi sangat baik. Desain pembelajaran LKPD telah memenuhi standar kurikulum dan desain instruksional yang baik. Penjabaran kurikulum dalam LKPD telah diturunkan menjadi Kompetensi dasar, indikator, dan tujuan pembelajaran. Tujuan pembelajaran telah dirumuskan dengan baik dan disajikan pada LKPD. Kemudian LKPD yang dikembangkan telah menerapkan desain pembelajaran mulai dari penyajian tujuan, pemberian motvasi, kejelasan, urutan materi, penyajian petunjuk kerja, penyajian 
langkah-langkah pemecahan masalah, penyajian media, hingga evaluasi. Desain pembelajaran yang dikemas dengan baik akan membuat pembelajaran siswa berlangsung secara sistematis dan menjadi bermakna sehingga akan berlangsung secara terarah dan terorganisir (Az Zafi \& Partono, 2020).

Hasil validasi LKPD berbasis pemecahan masalah dari hasil media pembelajaran berada pada kualifikasi baik. Pada aspek media dinilai komponen sampul, tipografi, gambar, dan tata letak. LKPD yang dikembangkan telah menggunakan sampul yang menarik, menggunakan tipe huruf san serif sehingga mudah dibaca oleh siswa. Tipe huruf ini memiliki tebal tipis yang jelas dan biasanya dipakai pada buku teks dan surat kabar (Monica, 2010). Gambar yang digunakan pada LKPD adalah konkret berwarna. Gambar ini akan memberikan daya tarik kepada siswa karena apa yang merekat lihat jelas dan dapat dimengerti. Tata letak dalam LPPD juga telah memperhatikan aspek kemudahan bagi siswa dan estetika. Materi atau aspek gambar yang dianggap penting disajikan pada bagian kiri atas sedangkan aspek yang menjadi pelengkap diletakkan pada bagian kanan sehingga hal ini menjadikan tata letak LKPD menjadi lebih baik. Dengan pengemasan LKPD sesuai prinsip-prinsip media yang baik maka dalam proses pembelajaran peserta didik dapat tertarik untuk belajar mengenai sesuatu hal yang baru dan dapat belajar secara mandiri menjadi efektif. Dengan demikian LKPD menjadi panduan yang layak bagi peserta didik dalam proses pembelajaran sehingga peserta didik dapat belajar secara aktif dan mampu belajar mandiri karena mengikuti petunjuk yang ada dalam LKPD (L. S. Rahayu et al., 2019).

Hasil uji coba LKPD berbasis pemecahan masalah pada tahap uji coba perorangan dan uji coba kelompok kecil berada pada kualifikasi sangat baik. Untuk mencapai kualifikasi tersebut terdapat beberapa hal yang membuat peserta didik tertarik dan termovitasi untuk belajar, yaitu LKPD yang dikembangkan memiliki desain yang terdiri dari banyak warna serta gambar yang relevan dengan materi yang dipelajari siswa. LKPD yang dikembangkan juga memiliki soal dalam bentuk kasus-kasus yang dapat membuat siswa berpikir lebih kritis karena soal yang dibuat dalam LKPD tersebut berbasis pemecahan masalah. Penyajian kasus-kasus ternyata dapat memberikan manfaat dan merupakan metode yang efektif bagi peserta didik dalam memecahkan masalah (Yoo \& Park, 2014). Kemampuan pemecahan masalah adalah hal yang penting diajarkan dalam pembelajaran karena kemampuan pemecahan masalah dapat berguna bagi kehidupan peserta didik sehari-hari (Rostika \& Junita, 2017). Implikasi hasil penelitian ini adalah LKPD dapat dikembangkan untuk materi lainnya dan harus disesuaikan desain pembelajarannnya dan isi mata pelajarannya. LKPD yang dikembangkan by design akan lebih sesuai dengan konteks dan karaktersitik siswa sehingga proses pembelajaran dapat berlangsung dengan efektif dan efisien (Diella \& Ardiansyah, 2019).

\section{Simpulan}

Berdasarkan pemaparan hasil dan pembahasan dapat disimpulkan bahwa pengembangan LKPD berbasis pemecahan masalah kontekstual menggunakan model ADDIE melalui empat tahapan yaitu analisis, desain, pengembangan dan evaluasi sehingga dihasilkan LKPD yang valid dan layak digunakan. Validitas aspek isi dan desain pembelajaran LKPD berada pada kualifikasi sangat baik sedangkan validitas aspek media berada pada kategori baik. Kelayakan LKPD pada tahap uji coba perorangan dan kelompok kecil berada pada kualifikasi sangat baik. Dengan demikian dapat disimpulkan pengembangan LKPD berbasis pemecahan masalah kontekstual adalah valid dan layak digunakan dalam kegiatan pembelajaran. Disarankan kepada pendidik untuk mengembangkan LKPD sesuai dengan konteks dan karakteristik peserta didik dengan memperhatikan aspek isi, media, dan desain pembelajaran. Hal yang tidak kalah penting adalah inovasi dalam sebuah LKPD sehingga dapat dihasilkan LKPD yang menarik dan mampu memotivasi siswa untuk belajar.

\section{Daftar Pustaka}

Agung, A. A. . (2010). Pengantar Evaluasi Pendidikan. Universitas Pendidikan Ganesha. 
Agung, A. A. . (2014). Metodologi Penelitian Pendidikan. Aditya Media Publishing.

Aprilia, A., Zuliani, R., Rini, C. P., \& Unaenah, E. (2020). Pengembangan Lks Berbasis Kontekstual Pada Mata Pelajaran Ipa Siswa Kelas Iv Sdn Pondok Pucung 01 Kota Tangerang Selatan. Indonesian Journal of Elementary Education, 2(1), 52-61.

Az Zafi, A., \& Partono, P. (2020). Desain Pembelajaran sebagai Upaya Peningkatan Kualitas Pembelajaran al-Quran Hadis. MATAN: Journal of Islam and Muslim Society, 2(1), https://doi.org/https://doi.org/10.20884/1.matan.2020.2.1.2292

16-25.

Cahyani, H., \& Setyawati, R. W. (2016). Pentingnya Peningkatan Kemampuan Pemecahan Masalah Melalui PBL untuk Mempersiapkan Generasi Unggul Menghadapi MEA. PRISMA, Prosiding Seminar Nasional Matematika, 151-160.

Diella, D., \& Ardiansyah, R. (2019). Pelatihan Pengembangan LKPD berbasis Keterampilan Proses Sains Dan Instrumen Asesmen KPS Bagi Guru IPA. Publikasi Pendidikan, 9(1), 7. https://doi.org/10.26858/publikan.v9i1.6855

Faridah, S., Mustaji, \& Tjipto, S. W. (2019). Pengaruh Contextual Teaching and Learning Terhadap Aktivitas Dan Hasil Belajar Siswa Pada Mata Pelajaran Ips Kelas Iv Sekolah Dasar. Jurnal Review Pendidikan Dasar: Jurnal Kajian Pendidikan Dan Hasil Penelitian, 5(3), 1092. https://doi.org/10.26740/jrpd.v5n3.p1092-1099

Hala, Y., Mushawwir Taiyeb, A., Negeri, S., Biologi, J., \& Negeri Makassar, U. (2016). Pengaruh Penggunaan Lembar Kerja Peserta Didik Berbasis Pendekatan IImiah Terhadap Aktivitas dan Hasil Belajar IPA Biologi Kelas VII Peserta Didik SMP $\begin{array}{lllll}\text { Negeri } 2 \text { Watampone. Jurnal Sainsmat, } & \text { V(1), }\end{array}$ http://ojs.unm.ac.id/index.php/sainsmat

Hanafi. (2017). Konsep Penelitian R \& D Dalam Bidang Pendidikan. Saintifika Islamica: Jurnal Kajian Keislaman, 4(2), 129-150.

Jowita, V., N. (2017). Pengembangan Lembar Kerja Peserta Didik (Lkpd) Menggunakan Model Problem Based Learning Pada Tema 4 Sehat Itu Penting Sebtema 3 Lingkungan Sehat Di Kelas V Sd Negeri 55/I Sridadi. 1-10.

Kristyowati, R. (2018). Lembar Kerja Peserta Didik (LKPD) IPA Sekolah Dasar Berorientasi Lingkungan. Prosiding Seminar Dan Diskusi Nasional Pendidikan Dasar 2018, 284.

Monica. (2010). Pengaruh Warna, Tipografi, dan Layout pada Situs. Humaniora, 1(2), 459-468.

Oktiani, I. (2017). Kreativitas Guru dalam Meningkatkan Motivasi Belajar Peserta Didik. Jurnal Kependidikan, 5(2), 216-232. https://doi.org/10.24090/jk.v5i2.1939

Pane, A., \& Darwis Dasopang, M. (2017). Belajar Dan Pembelajaran. FITRAH:Jurnal Kajian IImu-IImu Keislaman, 3(2), 333. https://doi.org/10.24952/fitrah.v3i2.945

Rahayu, D., \& Budiyono. (2018). Masalah Materi Bangun Datar. Pengembangan LKPD Berbasis Pemecahan Masalah Pengembangan, 06, 249-259.

Rahayu, L. S., Sony, I., \& Anggoro, S. (2019). Materi Volume Bangun Ruang Tak Beraturan Menggunakan Model Project Based Learning. 243-256.

Rahmawati, E. (2017). Meningkatkan hasil belajar pada siswa kelas IV sekolah dasar. 3(1), 346-350.

Rahmayanti, V. (2016). Pengaruh Minat Belajar Siswa dan Persepsi atas Upaya Guru dalam Memotivasi Belajar Siswa terhadap Prestasi Belajar Bahasa Indonesia Siswa SMP di Depok. SAP (Susunan Artikel Pendidikan), 1(2), 206-216. https://doi.org/10.30998/sap.v1i2.1027 
Rando, A. R. (2017). Pengembangan Perangkat Pembelajaran dalam Implementasi Strategi Contextual Teaching Learning untuk Meningkatkan Hasil Belajar IPS Pokok Bahasan Perkembangan Teknologi pada Siswa Kelas IV SD. Jurnal Pendidikan (Teori Dan Praktik), 1(1), 1. https://doi.org/10.26740/jp.v1n1.p1-12

Rey, G. D., \& Steib, N. (2013). The personalization effect in multimedia learning: The influence of dialect. Computers in Human Behavior, 29(5), 2022-2028. https://doi.org/10.1016/j.chb.2013.04.003

Rizki, M. (2018). Profil Pemecahan Masalah Kontekstual Matematika Oleh Siswa Kelompok Dasar. Jurnal Dinamika Penelitian: Media Komunikasi Sosial Keagamaan, 18(02), 271-286.

Rostika, D., \& Junita, H. (2017). Peningkatan Kemampuan Pemecahan Masalah Siswa SD dalam Pembelajaran Matematika Dengan Model Diskursus Multy Representation (DMR). EduHumaniora / Jurnal Pendidikan Dasar Kampus Cibiru, 9(1), 35. https://doi.org/10.17509/eh.v9i1.6176

Salim Nahdi, D., \& Cahyaningsih, U. (2018). Pengembangan Perangkat Pembelajaran Matematika Sd Kelas V Dengan Berbasis Pendekatan Saintifik Yang Berorientasi Pada Kemampuan Pemecahan Masalah Siswa. Jurnal Cakrawala Pendas, 5(1), 1-7. https://doi.org/10.31949/jcp.v5i1.1119

Suparlan, S. (2019). Teori Konstruktivisme dalam Pembelajaran. Islamika, 1(2), 79-88. https://doi.org/10.36088/islamika.v1i2.208

Suryani, I., Mardiati, Y., \& Herlanti, Y. (2019). Pengaruh Penggunaan Lembar Kerja Siswa (Lks) Berbasis Kontekstual Terhadap Hasil Belajar Siswa Pada Konsep Sistem Gerak Manusia. Edusains, 8(2), 150-156. https://doi.org/10.15408/es.v8i2.1823

Widodo, S. (2017). Pengembangan Lembar Kegiatan Peserta Didik (LKPD) berbasis Pendekatan Saintifik untuk Meningkatkan Keterampilan Penyelesaian Masalah Lingkungan Sekitar Peserta Didik di Sekolah Dasar. JPIS Jurnal Pendidikan IImu Sosial, 26(2), 189-204.

Widyanto, I. P. (2020). Peningkatan Mutu Pendidikan Hindu Melalui Pengelolaan $\begin{array}{llll}\text { Pembelajaran. Jurnal } & \text { Penjaminan }\end{array}$ https://doi.org/10.25078/jpm.v6i1.1151

Yoo, M. S., \& Park, J. H. (2014). Effect of case-based learning on the development of graduate nurses' problem-solving ability. Nurse Education Today, 34(1), 47-51. https://doi.org/10.1016/j.nedt.2013.02.014 